\title{
First Report of Alternaria alternata (Fr.) Keissler Causing Leaf Blight on Anthurium andraeanum in India
}

\author{
Thangeswari Selvaraj* and Sankaralingam Ambalavanan
}

Coconut Research Station, Veppankulam, Thanjavur, Tamil Nadu, India

*Corresponding author

\section{A B S T R A C T}

\section{Keywords \\ Anthurium, Leaf blight, Alternaria alternata}

Article Info

Accepted:

06 June 2018

Available Online:

10 July 2018
Leaf blight was observed in anthurium crop in Tamil Nadu and Kerala states of India during 2011-2012. Initially, the symptoms were small circular to irregular brown spots with concentric rings on the leaves that gradually enlarged. Fungal isolates, obtained from infected leaf tissues were grown in pure culture and on the basis of cultural and morphological characteristics and ribosomal DNA spacer sequences, the organism was identified as Alternaria alternata (Fr.) Keissler. To our knowledge this is the first report of Alternaria leaf blight disease in Anthurium andraeanum in India.

\section{Introduction}

Anthurium is an important cutflower crop which draws the attention of floriculturists in recent years and cutflower industry in India is fast expanding. Anthurium ranks eleventh in the global flower trade and commands a respectable price both for its cut flower and whole plant. Presently the Netherlands is the world's leading producer and exporter followed by Mauritius where it is also the national flower. In India, the anthurium cut flower industry is still in its infancy. The perusal of literature indicated that there have been a few reports on occurrence of fungal, bacterial and viral diseases on this crop. However, the occurrence of leaf blight disease was not mentioned in the literature. Taking clue from these, the roving survey was conducted in few major growing areas of Tamil Nadu and Kerala. In few isolated pockets, occurrence of unusual leaf blight with concentric rings symptom was observed. The disease was found to hamper the keeping quality of flower. With these back drop, this study was planned to characterize pathogen associated with the melody.

\section{Materials and Methods}

\section{Survey and collection of diseased samples}

Survey was conducted during 2010-2011 to assess the severity of leaf blight and 
anthracnose in different anthurium growing areas of Tamil Nadu and Kerala. Disease severity was recorded in 0-9 scale (Anonymous, 1980) and per cent disease index (PDI) was calculated. Infected samples of leaves were collected from these areas.

\section{Isolation and identification of pathogens}

The pathogens causing leaf blight in anthurium were isolated from the collected samples by tissue segment method (Rangaswami, 1958) and they were purified by single spore isolation and maintained on potato dextrose agar (PDA). The causal organisms were identified based on spore morphology. Identification of A. alternata being the first report on anthurium was further confirmed (ID.NO. 8580.12) by Indian Type Culture Collection Centre (ITCCC) of Division of Plant Pathology, Indian Agricultural Research Institute, New Delhi. The identification of leaf blight pathogen was further confirmed using the ITS primer (Jung et al., 2002). Genomic DNA was extracted from a suspension culture of A. alternata by the cetyltrimethyl ammonium bromide (CTAB) method as described by Knapp and Chandlee (1996). Specific primers for $18 \mathrm{~S}$ rDNA, ITS-F (5'- GTCCTAACAAG GTTTCCGTA-3'; AJ297952) and ITS-R (5'TTCTCCGCTTATTGATATGC-3';

AJ297953) were used to amplify an $\sim 650$ bp PCR amplicon of ITS region.

\section{Pathogenicity test}

The pathogenicity of purified cultures of $A$. alternata was confirmed by Koch's Postulates. Sporulating cultures of $A$. alternata were inoculated on PDA and incubated at room temperature $\left(28 \pm 2^{\circ} \mathrm{C}\right)$ to attain full growth. After incubation, the dishes were flooded with $10 \mathrm{ml}$ of distilled water and the spores were collected using a small brush. The spore suspension was filtered through a six-layersterile cheese cloth to remove mycelial debris.
Using a haemocytometer spore concentration of $A$. alternata was adjusted to $6 \times 10^{4}$ spores $\mathrm{ml}^{-1}$ respectively with distilled water. Single leaf inoculation technique was followed and the spore suspension was sprayed using a syringe until run-off on to the leaves of anthurium raised in glasshouse. Such single leaves were covered with polythene bags and symptom expression was observed regularly. Proper controls were also maintained.

\section{Results and Discussion}

\section{Survey, collection and assessment of PDI}

A Survey was conducted during 2010-2011 at five locations in Tamil Nadu and two places at Kerala to assess the intensity of leaf blight in anthurium. The leaf blight severity as per cent disease index (PDI) ranged from 12.20 to 56.34. The highest incidence of leaf blight was found in Coimbatore district of Tamil Nadu (56.34 PDI) followed by Wynad district of Kerala (44.33 PDI). The lowest incidence of leaf blight was observed in Thadiyankudisai, Dindugal district of Tamil Nadu (12.20 PDI).

\section{Symptomatology}

Symptoms were observed only on leaves and not on any other parts of plants. Initially small and brown spots were observed on leaves. Later, these spots were circular to irregular and brown to black with concentric rings and marginal blight with concentric rings (Fig. 1a and $1 b)$.

\section{Isolation and identification of the pathogen}

A total of ten times the isolation was repeated to confirm the association of pathogen with symptom. The causal organism was identified based on spore characters and colony morphology and they were purified by single spore isolation and maintained on PDA. 
Fig.1 Symptoms of leaf blight disease of anthurium and morphology of Alternaria alternata and morphology of $A$. alternata a brown spots with concentric rings $b$ marginal blight with concentric rings c colony of $A$. alternata on PDA d conidial mass of A. alternata e single conidia of $A$. alternata $\mathrm{f}$ healthy anthurium plant $\mathrm{g}$ leaf blight of anthurium 14 day after inoculation with A. alternata
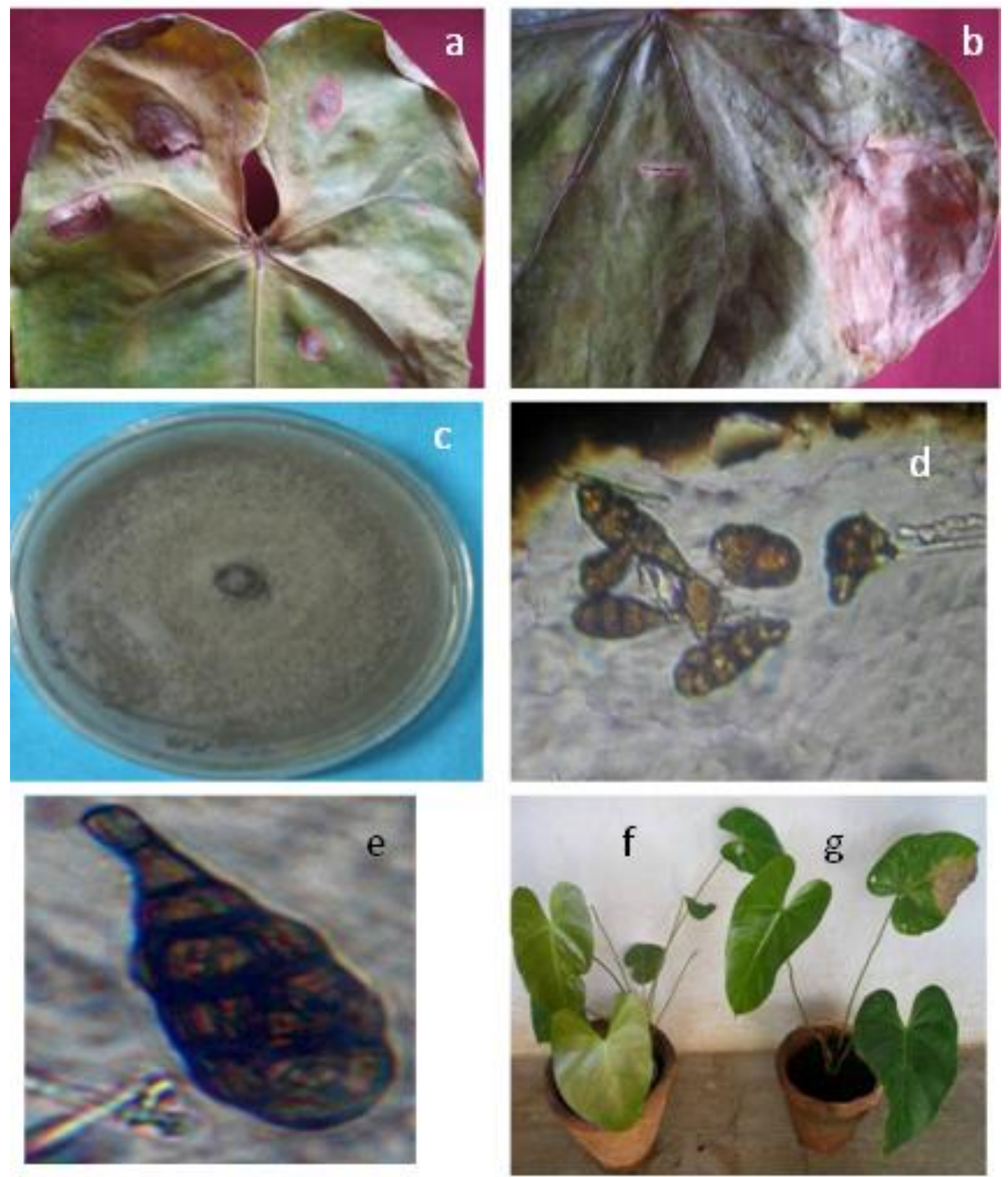
Fig.2 PCR amplification of ITS region of Alternaria alternate M 100 bp DNA ladder; Lanes 17 , isolates of $A$. alternata

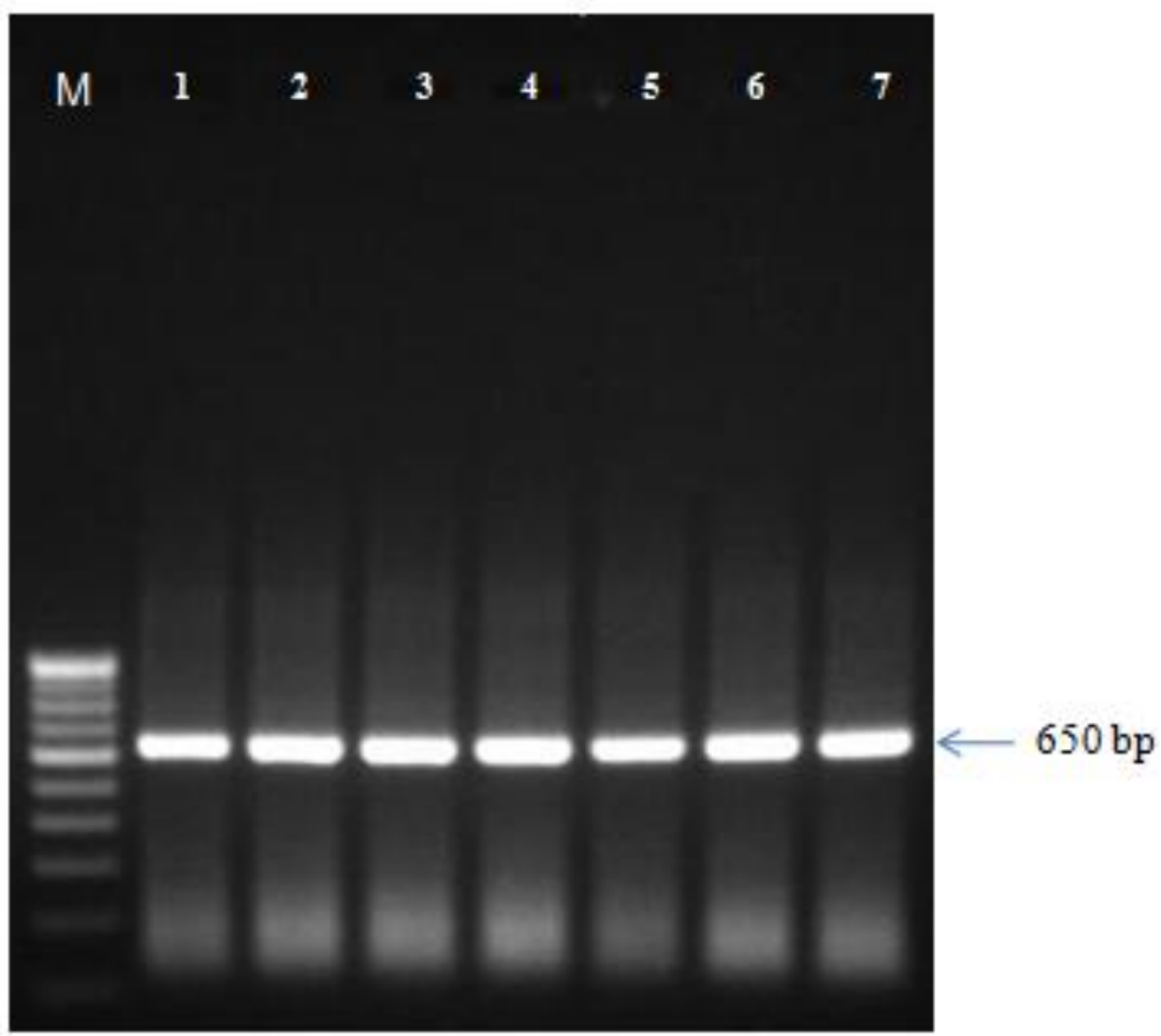

The fungus produced flat, downy to woolly and grey colonies with olive green peripheries. The Alternaria grew well on PDA and formed an olivaceous black colony with dark olive margins, reverse black at $28 \pm 2{ }^{\circ} \mathrm{C}$ after 10 days. The conidiophores were branched, straight pale brown to olive brown in colour. The conidia were pale brown to light brown in colour (Fig. 1c, 1d, and 1f). Based on the characters, the organism was identified as Alternaria alternata (Fr.) Keissler and further, the identification was confirmed by the Indian Type Culture Collection Centre, IARI, New Delhi, India (ID.NO. 8580.12). The ITS region of
Alternaria was amplified with the Alternaria 18 S rDNA specific primers ITS-F and ITSR to get $650 \mathrm{bp}$ PCR amplicon of ITS regions. All the seven isolates of Alternaria used in the study showed amplified product of the size 650 bp (Fig. 2).

\section{Pathogenicity}

Pathogenicity was performed by spraying leaves of 9 healthy 3 month-old potted $A$. andraeanum plants with a spore suspension of $6 \times 10^{4}$ spores per $\mathrm{ml}$. Control plants were sprayed with sterile water. Plants were covered with polythene bags for 2 weeks and 
kept on the glass house at $30 \pm 20^{\circ} \mathrm{C}$. After 2 weeks typical symptoms were produced on the inoculated leaves (Fig. 1f and 1g). Koch's postulates were fulfilled by consistently reisolating $A$. alternata from the lesions, where the control plants were remained symptomless. Inoculations were repeated twice with the same results. According to our studying thesis the first report of a disease caused by $A$. alternata on anthurium in India and we propose the name leaf blight.

\section{References}

Anonymous (1980). Score chart for crop diseases. Tamil Nadu Agricultural University, Coimbatore, 56pp.

Jung D S, Na Y J, Ryu K H (2002). Phylogenic analysis of Alternaria brassicicola producing bioactive metabolites. J. Microbiol. 40: 289-294

Knapp J E, Chandlee J M (1996). RNA/DNA mini prep from a single sample of orchid tissue. Biotechniques 21: 5456.

Rangaswami G (1958). An agar block technique for isolating soil micro organisms with special reference to Pythiaceous fungi. Sci. Cult. 24: 85

\section{How to cite this article:}

Thangeswari Selvaraj and Sankaralingam Ambalavanan. 2018. First Report of Alternaria alternata (Fr.) Keissler Causing Leaf Blight on Anthurium andraeanum in India. Int.J.Curr.Microbiol.App.Sci. 7(07): 646-650. doi: https://doi.org/10.20546/ijcmas.2018.707.078 